\title{
Bringing Brazil's resistance songs to London: words and music in translation
}

\author{
David Treece*
}

\begin{abstract}
Among the striking features of Brazil's current crisis, as progressive sectors contend with the relentlessly retrograde political and social agenda of Michel Temer's post-2016 government, are the echoes it has struck with earlier moments in the country's contemporary history of struggles to build and defend democracy. For many in today's pro-democracy movement, the slogans "Não ao golpe!" and "Diretas Já!" have explicitly connected the impeachment of President Dilma Rousseff and the call for general elections to the military coup of 1964 which overthrew president João Goulart, and to the 1984 demonstrations campaigning for an end to two decades of dictatorship, respectively (RochA, 2016). Also noteworthy is the fact that those historical resonances have often been mediated musically, as artists at events defending the diverse social causes under assault from Temer's reform agenda have mobilized their audiences by drawing on the power of the sung word.
\end{abstract}

While in April 2017 MC Chiquinho Divilas protested the government's pension and labour reforms using the idiom of rap (RAP..., 2017), and Rio de Janeiro's carnival parade in the same year included samba school Imperatriz Leopoldinense's theme "Xingu, o clamor que vem da floresta" in defence of the Amazonian forest communities and their environment (CAHE..., 2017), other performers have consciously bridged generations of anti-authoritarian dissent by recalling the words and melodies of songs from the 1960 os and 7os. Joining a movement of artists protesting against the closure of the Ministry of Culture in May 2016, veteran tropicalista Caetano Veloso performed two of the experimental compositions, "Alegria, Alegria" and "Tropicália", that had led to his imprisonment and exile in 1968 (MARTín, 2016). In a July show that same year at Rio de Janeiro's Circo Voador, Geraldo Azevedo followed invitations to the audience to join him in chants of "Fora, Temer" with a rendition of his 1968 "Canção da Despedida", co-authored with Geraldo Vandré in repudiation of the military regime (CONTRA..., 2016). And in the following month, Chico Buarque reprised perhaps the most loved antidictatorship anthem of all, his 1970 "Apesar de você", in a performance at the historic Canecão venue, which was occupied as part of the protests to reinstate the Ministry of Culture. Brasil de Fato magazine's compilation of the best eight viral

\footnotetext{
Camões Professor of Portuguese at King's College London, United Kingdom. E-mail: david.treece@kcl.ac.uk
} 
videos calling for the expulsion of President Temer included a Paris street orchestra's arrangement of "Apesar de você" (8 MeLHORES..., 2016).

Such examples as this are highly suggestive of the lasting resonance and appeal of popular songs as a repository of political memory, and of their capacity to project the reverberations of that memory across an inter-generational community of listeners, to articulate identifications of affect between individuals and groups of people both separated and connected by nearly fifty years of history. If it is one thing to examine the significance of compositions and performances in their country and context of origin, however, it is another to consider what meanings they might carry across a further leap in cultural time and space, when heard by communities of listeners abroad, say, in present-day London. What inherent potential resides in the musical and thematic structures of such songs, in their lyrical dramas, their melodies and rhythms, for them to be re-lived by nonBrazilians in ways that can mobilize and articulate ideas and feelings comparable, if not identical, to those experienced by earlier listeners? What acts of translation are possible and necessary to realise that potential, and what is the specific role of textual translation and of language in this, as a partner with music in the unique art-form that is song?

With those questions in mind, this essay reflects briefly on a practical, performance-based interactive project undertaken with London audiences between July and October 2017, entitled "The São Paulo Tapes: Brazilian Resistance Songs Workshops". "The first stage of an ongoing collaborative artistic project funded by an Arts Council of England Grant for the Arts, the Brazilian Resistance Songs Workshops were devised by vocal artist, songwriter and journalist Mônica Vasconcelos and myself, a translator-academic, in response to a shared perception (and frustration) concerning the simultaneous success and limitations of performing Brazilian songs for UK audiences. Vasconcelos's twenty-five years' experience as a London-based recording artist and performer of Brazil's MPB repertoire across venues in the UK and Europe leaves no doubt as to the growing interest in, and appreciation of that body of work among English-speaking audiences, as far as its solely musical (melodic, harmonic, rhythmic, stylistic) aspects are concerned. But what becomes of the lyrical, thematic dimension of the repertoire, and of its contribution to meaning, when the songs are heard abroad by non-speakers of Portuguese?

The consummate artistry of the MPB songwriting tradition, as established from the late 1950 os by the founders of Bossa Nova, Tom (Antônio Carlos) Jobim and Vinicius de Moraes, lies in an exceptional mastery of both of its creative components, the musical and the poetic, in a seamless fusion which, at its best, makes us believe that melody and speech were always and forever of a piece, improvised and shaped out of the simultaneously musical and linguistic contours of intona-

\footnotetext{
For a short documentary account of the first workshop, held at King's College London on 7 July 2017, see https://www.youtube.com/watch?v=Z9JvLk51JNI\&feature=youtu.be
} 
tion, phrase and accent (TREeCE, 2013, p. 64-65). As I shall argue below, the lyric has no greater or lesser claim than the melody to be the heart of a song's "content" or meaning; yes, it may be the bearer of verbal information, as narrative, declamation, conversation, confession or wisdom, but as language materialized sonically in time it is also so much more than mere "text". However intense our appreciation of a song's inventive use of melody, rhythm and harmony, it is only when those musical structures become voiced, intoned linguistically as discourse, that their full meaning becomes realized. A fine singing voice can express a great deal in musical terms alone, but when we hear and understand the language of song, as language-in-song, we share not only in the histories or thinking of another culture, we also gain access to its sensibility, to the deep articulations of social experience that are both mental and physiological, both linguistic and embodied - its "structures of feeling", to adapt Raymond Williams's formulation (Williams, 1977, p. 131). Song is therefore infinitely, profoundly more than the sum of its parts, and each of them - music and language - is always disastrously diminished in the absence of the other.

Elsewhere I have explored how the internationalization of Bossa Nova in the 1960s, as a mainly instrumental style, involved the dismemberment of its songs' melodic-discursive integrity, and how the very limited, and problematic, experience of lyric translation arguably helped to shape its rather mixed reputation in the English-speaking world (Treece, 2015). In her essay "Travelling Songs: On Popular Music Transfer and Translation", Isabelle Marc characterises the phases of musical transnationalism through which songs produced in one national setting can eventually become incorporated into another society's cultural and linguistic universe (MARC, 2015). The processes of reception and adaptation that Marc describes as leading to the travelling songs' detachment from their source cultures apply, but only partially so, to a small number of examples from the Bossa Nova repertoire, such as "Garota de Ipanema", and "Águas de março". Meanwhile, since most of the MPB repertoire is altogether untranslated, its British and American audiences are generally denied access not only to the stories, dramas and experiences encoded in its words, but also to the expressive function of the lyrics as formulated above, as language-in-song.

To move toward addressing this deficiency, the Brazilian Resistance Songs Workshops drew upon the resources developed to accompany The São Paulo Tapes (VASCONCELOS 2017), Vasconcelos's recently released cd album of new arrangements of selected songs by Chico Buarque, Geraldo Vandré, João Bosco \& Aldir Blanc, Ivan Lins \& Vitor Martins, Gonzaguinha, Taiguara and Caetano Veloso, among others, representing some of the most expressive responses to the experience of the 1964-85 dictatorship. A cd insert includes English commentaries on the songs, authored by Treece, while a downloadable poster ${ }^{2}$ provides the complete song lyrics in both the original Portuguese and in English versions by Treece.

\footnotetext{
2 See: <http://www.monicavasconcelos.com/saopaulotapes.html>.
} 
Each of the three workshops was held at a different geographical venue across London with a view to attracting a diversity of participants including family museumgoers (Horniman Museum), jazz aficionados (Vortex Jazz Club), students (King's College London) and arts audiences \& tourists (all three). Between 15 and 35 participants attended each workshop, which explored 2-3 songs taken from the album and the wider repertoire, in a structured dialogue between the workshop leader (Treece), performer (Vasconcelos, accompanied by guitarist Ife Tolentino) and participants, supported by audio-visual materials illustrating relevant cultural concepts, historical events and personages. A key element of the format was the decision first to share the participants' and performer's responses to the auditory/musical experience of the songs' melodic, rhythmic, architectural and stylistic character (as heard in live performance) before viewing or discussing the lyrics in their Portuguese and English versions. I shall return below to the significance of this approach, which yielded many rich insights, when I discuss how the construction of meaning, and in particular the idea of resistance, might be articulated in the interplay between the musical movement and the lyrical unfolding of the songs.

My understanding of these issues is informed by ongoing reflections on the character of Brazilian song composition since undertaking an early study of the post-Bossa Nova wave of politicized compositions in the years immediately before and after the 1964 military coup (TREECE, 1997). In that essay, I commented on Brazilian critic Walnice Nogueira Galvão's rather pessimistic 1968 appraisal of the "protest song" of those years. Based on an ideological reading of the song repertoire, Galvão had criticised its tendency to replace one mythology - Bossa Nova's "escapist complacency" - with another, "o dia virá" (the day will come), whose promise of redemption in some distant utopian future reassuringly absolved its listeners of responsibility for political action in the here and now (GALVÃO 1976). My response to Galvão's argument was that, in the absence of a viable mass movement capable of challenging the dictatorship from below, the idealism of the artistic-intellectual left was an inevitable corollary of its political isolation from the povo in whose name it claimed to speak - a position that I believe remains valid.

However, my other objection, which I did not develop at length, was that Galvão's evidence was exclusively textual; it therefore effectively reduced the meaning of song to its purely discursive, ideological "message", while ignoring the material and symbolic force of the music, including the sung voice, as a performative act. While we should not over-estimate the efficacy of music as a transformative political act in and of itself, I would now suggest that, when articulated together, both musically and discursively, the ideas of potentiality, imminence, anticipation and refusal that are encapsulated in the refrain "o dia virá" take on a more powerful mobilizing charge than Galvão attributes to the lyrical message alone. Indeed, it is striking that this theme is represented prominently in the repertoire selected for The São Paulo Tapes and in the Brazilian Resistance Songs Workshops, since it continued to be explored by many of the best songwriters after 1968 
Abre a${ }_{- \text {-las pra mi- }}^{-}{ }^{-a}$

Make way $-a$

$$
\text { Já está chegan- }
$$

$$
{ }_{\text {is dra- }}^{\text {-wing nea- }}{ }^{-r e r}
$$

A-<smiles>[Mg][Mg][Mg]</smiles>

vo-
A$\begin{array}{llll}\text {-ma- } & \text { há } & & \text { ou- } \\ \text {-nhã } & & \text { ser } & \text {-tro }\end{array}$

di$-a$

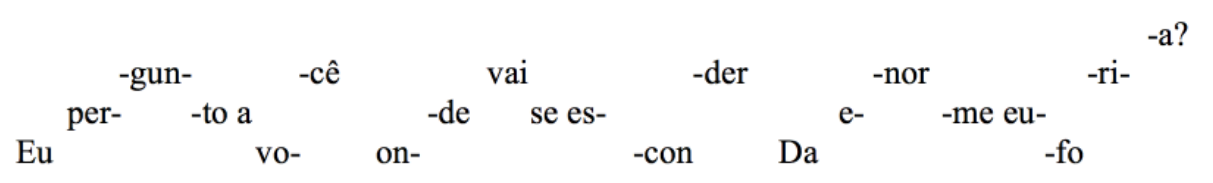

even though, or perhaps because, the post-1968 "anos de chumbo" of hardline repression rendered extremely problematic the prospect of successful organized political resistance in the immediate present. Compositions such as Chico Buarque's "Apesar de você" (1970) or "Abre Alas" (1974), by Ivan Lins and Vítor Martins, exemplify that juncture of linguistic articulation and somatic mobilization that does not merely convey the desire for emancipation; rather (as suggested here schematically), in a dual, downward and upward melodic-discursive movement (which was immediately evident to our workshop participants), it rehearses, enacts and performs its realization, rendering actions as words, and words as actions:

This pattern of musical and lyrical movement, and the theme of imminence that it enacts, is of course just one option - the imagining of "carnivals to come" - in the repertoire of resistance songs that span the period before and after 1968. Before elaborating on that repertoire by setting out a more extensive typology of genres and idioms, it is worth commenting further on the impact of the 1968 watershed, the moment of the "coup within the coup", on the oppositional songwriting of the period, and its significance for our choice of the term "resistance" rather than "protest".

As Ricardo Santhiago has argued, when applying the broad notion of "protest music" to Brazil, the post-1964 period of military rule should not be privileged 
at the expense of other political and cultural moments across the history of the last century: "Protest proved to be an integral part of twentieth-century Brazilian music, not limited to what was sung under the military dictatorship. It has often been favored where inflamed political emotions are shared by its authors and listeners, who understand music as a connection between those two poles and even between a current, unpleasant, situation and a positive, utopian, future" (SANTHIAGO, 2013, p. 301). But perhaps more significant for our purposes than simply this general connection between the political status quo and its antithesis is the mode of response to the experience of oppression or repression. Here we could distinguish between explicit statements of opposition to a given political, economic or social regime ("protest"), and a more coded or opaque expression of dissidence in relation to the status quo, recalling George Lipsitz's concept of "immanent resistance" (Lipsitz, 1994). We can find another useful approach in Robert Pring-Mill's work on political songs in revolutionary Nicaragua, where he discarded what he saw as the narrowly denunciatory connotations of the term "protest song" in favour of the designation "songs of hope and struggle", which "nicely stresses both their 'combative' and their 'constructive' aspects, while one of the best of their singers - the Uruguayan Daniel Viglietti - describes his own songs as being 'in some measure both de protesta and de propuesta' (i.e. as much 'proposing' as they are 'protesting')" (PrING-MiLL, 1987, p. 179).

In Brazil, the combative and denunciatory modes of protest were most characteristic of that peculiar interlude of the Castelo Branco administration, before the draconian crackdown of 1968, when the targets of state repression were the rankand-file organisers of workers, peasants, soldiers and sailors, while leftwing artistic and intellectual activity was allowed to flourish relatively undisturbed. Within the competitive space of the televised song festivals organised by the Globo and Record networks, this brief period saw a remarkable explosion of creative innovation, much of it arising from dialogues between the by now established idiom of Bossa Nova and the traditions associated with Brazil's urban and rural masses or povo. This process of hybridization reflected the aspirations of the artistic, intellectual and student left, which saw the project of a politicized cultura popular as the key instrument in the struggle to both educate and mobilize a broad popular movement for progressive, democratic grassroots reform (TREECE, 1997).

Starting with a thematic typology, we can identify three broad discursive categories in this period, whose function was to dramatize the spectacle of popular oppression and resistance, to inform and to mobilize, and to bring about a transformation in the listener's political consciousness:

1. Dramas of popular struggle: examples include (a) roots sambista Zé Keti's tithe song for the 1964 stage musical Opinião, an Arena Theatre production directed by Augusto Boal with members of the Popular Culture Centre (CPC); Keti's defiant "opinion" unapologetically voices both his right to speak in the face of repression, and his unbreakable bonds with the hillside morro, the material and symbolic locus 
of black working-class identity: "Podem me prender / Podem me bater / Podem até deixar-me sem comer / Que eu não mudo de opinião / Daqui do morro / Eu não saio, não" (They can arrest me/ They can beat me/ And they can leave me to starve/ For I won't change my mind/ No, I'll not leave this place, my hillside); (b) Sérgio Ricardo's dramatization of the factory-worker's daily existence in "A Fábrica" (1964), which shifts between the rhythms of the shop-floor regime and a husband's frustrated dreams of a better life; and (c) João do Vale and José Cândido's "Carcará", another contribution to the Opinião musical, which combines the traditional modal scales of Brazil's rural Northeast with the cross-rhythms of samba and baião to depict the resilience and tenacity of the region's migrants, in the shape of a formidable bird of prey. Mônica Vasconcelos's rendition of the song, like Maria Bethânia's 1964 performance, exploits to the full the expressive force of musical and prosodic syncopation, in the aggressively assymetrical stresses of the refrain:

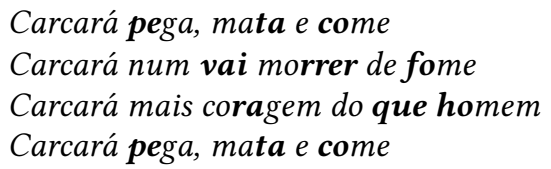

Carcará he catches, kills and eats

Carcará ain't gonna starve

Carcará he's more courage than a man

Carcará he catches, kills and eats

2. Popular culture as struggle - the Afro-samba: moving beyond these depictions of working-class struggle, a second tendency, represented especially by the Baden Powell/Vinicius de Moraes partnership and by collaborations led by Edu Lobo, sought instead to evoke and celebrate musically a spirit of popular resistance in the rhythms, melodies and language of Afro-Brazilian religious culture. "Cantos" or chants, often associated with orixás or deities from the Yoruba pantheon ("Canto de Ossanha", "Canto de Xangô") and linked to ritualized activities such as dance, worship and physical combat, provide the rhetorical and musical structures for compositions expressing solidarity and action through prayer and movement. So, for example, "Berimbau" (BAden Powell/Moraes, 1963) is constructed, both rhythmically and melodically, around the two-tone pattern played on the percussion bow (berimbau) which accompanies the combat game of capoeira. This oscillating binary figure corresponds to the dynamic equilibrium enacted in the game, both in its choreography and in the aphorisms of its verses, which demand integrity, love and honesty in the midst of struggle:

Quem de dentro de si

O dinheiro de quem

Capoeira que é bom

$$
\begin{array}{lll}
\text { Não sai! } & \text { Vai morrer sem amar } & \text { Ninguém! } \\
\text { Não dá! } & \text { É o trabalho de quem } & \text { Não tem! } \\
& \text { Cai bem!... } \\
\text { Não cai! } \quad \text { É se um dia ele cai } &
\end{array}
$$

(He who won't come out of himself! / Will die without loving a soul! / The money of him who won't give! / Is the labour of him who has none! 
/ The capoeira who is good won't fall! / And if one day he falls, he'll fall well!).

3. Conscientização - didacticism and mobilization: a third approach is typified by the rhetoric of enlightenment and exhortation, in which voices of experience, insight and inspiration "speak truth to power" and rally their listeners to collective action. For example, Carlos Lyra and Gianfrancesco Guarnieri's anti-romantic depiction of the favela, "O Morro (Feio não é bonito)", opens in carnivalesque sambaenredo style with the familiar sound of a unisson female chorus patriotically celebrating the riches of Afro-Brazilian heritage, but it then sets against this a solo voice speaking of a different, unofficial history, that of the hillside which "Chora, mas chora rindo/ Porque é valente/ E nunca se deixa quebrar". Geraldo Vandré's "Pra não dizer que não falei das flores (Caminhando)", meanwhile, became the organised left's anthem of protest, especially after its acclamation in September 1968 by the audience at the TV Globo 3rd International Song Festival, its subsequent prohibition by the regime, and Vandré's forced exile. The song's simple twochord structure, sombre melody and pedestrian rhythm were a transparent, functional vehicle for its appeal to universal solidarity and its call to action: "Vem, vamos embora/ Que esperar não é saber/ Quem sabe faz a hora/ Não espera acontecer" (Come, let's get going/ By waiting we'll never know/ If you know, you make your time/ You don't wait for it to come). And in Vandré's "Disparada” (Stampede, 1966), co-written with Theo de Barros, it is the energetic rural proletarian sound of the moda de viola, a ballad-like recitative form found across Brazil's peasant and cattle-farming hinterland, which serves to project the storyteller's revolutionary lesson of life. A once lowly herdsman, an archetypal "man of the people", recounts how a glimpse of power led him to an epiphany, to an understanding of the injustice of a world in which men are treated like cattle; now that he has become the master of his life he can challenge his listeners to choose between enlightenment or ignorance and to follow him in his dream of emancipation and equality:

\author{
Mas o mundo foi rodando \\ Nas patas do meu cavalo \\ E nos sonhos que fui sonhando \\ As visões se clareando \\ Até que um dia acordei \\ E já que um dia montei \\ Agora sou cavaleiro \\ Laço firme e braço forte \\ Num reino que não tem rei
}

\author{
But the world it went on turning \\ Beneath my horse's hooves \\ And in the dreams that I kept dreaming \\ My view of things came clearer \\ Until one day I was wide awake \\ And since I climbed into the saddle \\ Now a horseman is what I am \\ Strong-armed and steady with the rope \\ In a kingdom without a king
}

A notable feature of the songwriting of this phase is an isomorphic correspondence between musical idiom and thematic discourse, a unity of rhythm and speech, genre and rhetoric, which means that each specific musical style effectively comes to symbolize a category of social protest - samba as the voice 
of the morro, of historic, post-Abolition urban working-class struggle; the marcha/marchinha as the rallying call for the povo to take to the streets; the afrosamba as the ritualised expression of black spirituality in motion, and the moda de viola as the didactic voice of harsh experience and revolutionary action. Style and subject, idiom and ideology are unproblematically integrated into a single, univocal rhetoric of defiance or combat which leaves no room for ambiguity or "cognitive dissonance", so to speak, for the human frailties and complexities of suffering and resistance when lived at the level of individual subjectivity.

But after the 1968 watershed that turn to lyrical subjectivity became a necessity; with the proclamation of Institutional Act No. 5, suspending all constitutional guarantees, a draconian new regime of arbitrary arrest, imprisonment, torture and censorship closed down entirely the space for free, collective expressions of public protest and made it a dangerous, punishable act to speak explicitly the language of denunciation or mobilization. Deprived of the street, the mass media and the televised contest as arenas for constructing a communal consciousness between artist and audience, that relationship became privatized and virtualized, passing into the realm of complicity, of shared confidences, of coded, allegorized or metaphorized dramas of individual experience. In other words, in order to discover new possibilities for resistance in song, the political now had to become intensely personal, concerned with a common identity of feeling as much as of thought, and its poetic-musical language was now therefore essentially lyrical.

The repertoire explored in the The São Paulo Tapes and in the Brazilian Resistance Songs Workshops draws especially on this lyrical mode of songwriting, which sets the subjective experience of dictatorship (lived as pain, loss, incomprehension or fear) against individual dramas of resistance to it in the form of testimony, historical memory, anger, hope, questioning and even refusal. And it is here, especially, that the role of textual translation becomes crucial: whether, as in our practice, through the medium of printed lyric sheets, as spoken recitations preceding the live performance of the songs, or as a resource for the exploratory dialogues among the participants of our workshops. Of course, given the frequent complexity and obscurity of the metaphorical and allegorical imagery to which lyricists such Aldir Blanc resorted to evade the control of the censors, even a simple prose translation will be indispensable to decode the songwriters' intentions; for example, in comparing the censored and uncensored versions of "O Mestre Sala dos Mares" (1975), by João Bosco \& Aldir Blanc, where the "Black Admiral" João Cândido Felisberto, the leader of the 1910 Revolt of the Lash, is reimagined as a "Master of Ceremonies" of the Seas, a magical samba dancer leading the Carnival parade with his choreographic wizardry [censored text in square brackets]:

\footnotetext{
Rubras cascatas jorravam das costas Dos santos entre cantos e chibatas Cascades of crimson poured down the backs [Dos negros pelas pontas das chibatas] Of saints amid chants and lashes Inundando o coração do pessoal do porão [Of the blacks from the lashes' tips] Flooding the hearts of the people below decks
} 
Que a exemplo do feiticeiro gritava então: [Que a exemplo do marinheiro gritava - não!]
Who took up the sorcerer's cries shouting then: [Who took up the mariner's cry, shouting $-n o$ !]

But the conveyance of semantic information is not the only, nor arguably the most important, role for translation in making possible a fuller appreciation of what is at stake in this lyrical mode of resistance song. If the text-melody is no longer a mere vehicle for objective dramas of popular struggle and their ideological truths, but is now more concerned with the experience of resistance as affect, as something enacted subjectively in the realm of feeling, then we must return to our concept of language-in-song, to the structures of linguistic and musical articulation which move the listener through the song's emotional narrative. The insistence, in our workshops, on first discussing the participants' and artist's "feeling" for the songs' unfolding, before studying their texts in detail, is aimed at identifying those dynamic structures, and at focusing on how we grasp their sense as movement, following Luis Tatit's insight about the special character of this artform: "In the world of the songwriters it is not so much what is said that matters but the manner in which it is said, and the manner is essentially melodic" (TATIT, 1996, p. 9). The lyric translation may help the non-Portuguese listener to appreciate that sense of movement by reproducing, not only the lexical and semantic features of the original, but also its prosodic architecture, the unique diction which shapes how the dynamic features of phrase, melody and rhythm appear naturally to coincide and create an impression of affective "truth", the illusion that this marriage of words and music must always, already have been conceived thus.

In "Aparecida" (1977), by Ivan Lins \& Maurício Tapajós, the diction is that of bewildered incomprehension, as an abandoned lover's unanswered questions ironically reveal the double meaning of his woman's absence, encapsulated in the wordplay of "Diz Aparecida/ desaparecida". What could simply be a personal lifechanging tragedy, the mysterious cause of Aparecida's emotional silence, takes on a second, more disturbingly political significance, the trauma of enforced, illegal disappearance, with its implications of torture. By the same token, the reiterated appeal to Aparecida to speak up is heard as both a plea for emotional honesty and a demand for political truth:

Diz Aparecida

Me conta por onde que você andou

Me conta por que é que você

Não tem mais aquela afeição

Não tem mais aquela euforia

Não tem mais a mesma paixão

Diz Aparecida

Sumir desse jeito não tem cabimento

Me conta quem foi, por que foi

E tudo que você passou
Say, Aparecida

Tell me what's wrong, where you disappeared to

What happened to make you this way

What happened that your love's gone away

What happened that your joy's gone away

What happened that your passion's all gone

Say, Aparecida

To vanish that way there's no rhyme or reason

Won't you tell me the who and the why

And all that you had to go through 
Preciso saber seu tormento Preciso saber da aflição

Diz Aparecida

Diz, conta o segredo

Diz e denuncia

Que a verdade escondida

É mentira, é medo

Ah diz, Aparecida

Me diz, Aparecida
Let me know the torment you suffered inside

Let me know the distress you endured

Say, Aparecida

Speak, and break the silence

Speak, there's no denying

When you hide the truth there's only

There's only fear and lying

Oh say, Aparecida

Speak, Aparecida

It is worth noting the importance, in these songs' testimonial expression of pain and regret, of the principle of reiteration, whether in the form of parallel musicaldiscursive structures, anaphora, or interrogative repetition. In "Aos Nossos Filhos" (IVAN Lins \& VITOR MARTINS, 1978) this principle of reiteration serves to voice an apology "To our children", to the children of the dictatorship generation - more specifically perhaps those of Brazil's clandestine resistance, its exiles and guerrilla fighters - for the deprivation of lives lived in insecurity, loneliness and the fear of repression:

$\begin{array}{ll}\text { Perdoem a cara amarrada } & \text { I'm sorry for the frown on my face } \\ \text { Perdoem a falta de abraço } & \text { I'm sorry for not holding you more } \\ \begin{array}{l}\text { Perdoem a falta de espaço } \\ \text { Os dias eram assim }\end{array} & \text { I'm sorry there wasn't more space } \\ & \text { It's just the way that things were before } \\ & \text { I'm sorry for so many dangers } \\ \text { Perdoem por tantos perigos } & \text { I'm sorry for not sheltering you more } \\ \text { Perdoem a falta de abrigo } & \text { I'm sorry there weren't more friends for you } \\ \text { Perdoem a falta de amigos } & \text { It's just the way that things were before } \\ \text { Os dias eram assim } & \end{array}$

In Miltinho and Chico Buarque's "Angélica" (1981), meanwhile, each of the four (or, in performance, more) iterations of the core strophic form rehearses a dialogue between two voices: on the one hand the questioning witness, asking to be told the identity of the enigmatic woman who is "always singing that lament"; and on the other, the speaking/singing mother herself, who in turn bears witness to the loss of her son, while refusing to give up her search for him. "Angélica" was dedicated to Zuzu Angel, whose son, student activist Stuart Angel Jones, was murdered following his arrest and torture by the military authorities in 1971. The song's seemingly endless dialogic structure, intensified in the arrangement recorded by Mônica Vasconcelos by the theme's rising modulations, not only dramatizes but also enacts Zuzu's relentless pursuit of the truth, her tireless questioning - in the press, at the headquarters of the regime's military officers, even abroad in the US - and her undying hope of finding some trace of her child:

Quem é essa mulher

Que canta sempre esse estribilho

Só queria embalar meu filho
Who is that woman there Always singing that refrain

I just wanted to rock my little boy 
Que mora na escuridão do mar

Quem é essa mulher

Que canta como dobra um sino

Queria cantar por meu menino

Que ele já não pode mais cantar
Who dwells in the dark of the sea

Who is that woman there

Singing the way a bell tolls

I wanted to sing for my little boy

For he can no longer sing

Alternatively, the emotional and semantic architecture of the song can be built around radical shifts and contrasts in prosodic form, musical pace and mood, as in "Agnus Sei" (1972), by João Bosco \& Aldir Blanc. Workshop participants asked to describe their responses to the unfolding sonic structure of this song spoke perceptively of the brooding, threatening movement of the verses' rising and falling theme, and the urgent forward momentum of the refrain, with its final sequence of rhythmic punctuations culminating in a single "Não!" These contrasting forms and dictions counterpose two aspects of the song's obscure allegorical drama, which draws a critical analogy between the ideological battles of contemporary Brazil and the medieval religious wars between Christians and Muslims. The anti-Communist rhetoric of the 1964 "Freedom Marches in the name of Family and God", which heralded the military coup, is implicitly likened to the Crusaders' justification of their anti-Islamic campaigns of slaughter in the language of "Just War". But in a moment of insight, an innocent conscript to this war, a "Lamb of God", reveals himself instead to be a black sheep, the bearer of dangerous, subversive knowledge that leads him to a lonely, brave act of disobedience:

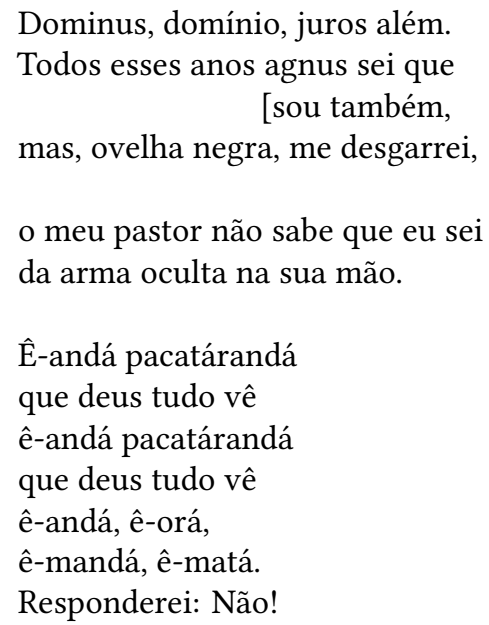

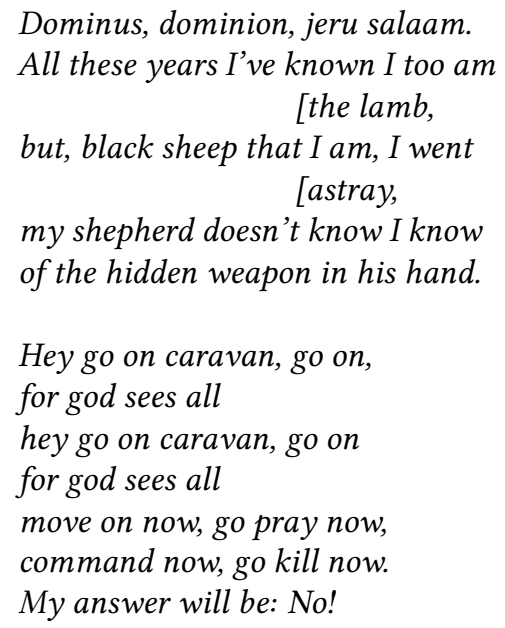

Finally, to conclude this exposition of the lyrical mode of songwriting that is the focus of The Brazilian Resistance Songs project, a rather different composition from the Bosco/Blanc partnership takes us away from both the reiterative model of "Aos Nossos Filhos" and "Angélica", and also from the contrastive approach of "Agnus Sei". In "O Bêbado e a Equilibrista" (The Drunkard and the Tightropewalker, 1978), a disconsolate vision of a Brazil in a state of calamity and grief is jux- 
taposed with glimpses of hope, represented by two figures: a Chaplinesque drunkard, with his associations of subversive mischief, and a fearless acrobat precariously poised on the tightrope. The melodic-discursive idiom that Bosco and Blanc together find here, to express this fragile balance between despair and redemption, is an extraordinarily beautiful achievement. Although its melody undergoes one reiteration, it nevertheless appears to take the form of a simple unbroken lyrical utterance or breath, shaped out of arabesque leaps and falls, pirouettes, echoes, end-rhymes and internal rhymes. It gives the impression that it is somehow both structured and free-form, a rhapsodic, dream-like improvisation in tempo rubato, which mimics the playful, drunken choreography of its protagonists in the seemingly spontaneous partnership of word and melody, of language-in-song:

Caía a tarde feito um viaduto

E um bêbado trajando luto me [lembrou Carlitos

A lua tal qual a dona do bordel

Pedia a cada estrela fria um brilho de aluguel

E nuvens lá no mata-borrão do céu

Chupavam manchas torturadas, que sufoco [louco

O bêbado com chapéu coco fazia [irreverências mil

Prá noite do Brasil, meu Brasil

Que sonha com a volta do irmão do Henfil

Com tanta gente que partiu num rabo de [foguete

Chora a nossa pátria mãe gentil

Choram marias e clarisses no solo do Brasil

Mas sei que uma dor assim pungente [não há de ser inutilmente

A esperança dança na corda bamba de [sombrinha

E em cada passo dessa linha pode se machucar

Azar, a esperança equilibrista

Sabe que o show de todo artista tem [que continuar
The evening fell like a bridge's crashing [arches

A drunkard dressed in mourning made [me think of Charlie Chaplin

The moon, like the madam of some [bordello

Asked every star if it would sell its little [bit of yellow

And clouds up in the blotting-paper sky

Soaked up the tortured stains of some [unholy nightmare, right there

The mournful bowler-hatted drunkard [bowed insolently to the night

The night that is Brazil, my Brazil

Who dreams that Henfil's brother will [return

So many others said farewell in a sea [of troubles

She's weeping, our dear sweet motherland [is weeping

Marias and clarisses weep into Brazil's [good soil

I know, I know that all this searing pain [can't ever truly be in vain

There's one more chance to dance, hope [walks the wire forever knowing

At every step she could be going to fall [and come to harm

No harm, she's up there poised upon her [toes

Hope knows what every artist knows that [the show must go on

As a vision of hope and resistance to tyranny, in the version performed by Elis Regina "O Bêbado e a Equilibrista" became the voice of the amnesty campaign for those prosecuted for crimes under the military dictatorship, which led to the 
passing of the 1979 Lei da Anistia. In late 2017 and early 2018, this memory was given unexpected new resonances, in the context of the Temer administration's assaults on basic democratic principles of citizenship and freedom of expression. From July that year, the song's original meaning was reclaimed in a series of performances by the singer Ana Canãs in support of speeches by ex-President Luiz Inácio Lula da Silva, during the appeal campaign against his prosecution on corruption charges (see https://youtu.be/nziudCpqQrs and EM ATO..., 2018). In a bizarre turn, however, on 6 December 2017 senior members of the Federal University of Minas Gerais, including its Rector and Vice-Rector, were detained without warning by agents of the Federal Police for questioning regarding the construction of an Amnesty Memorial (MArTins, 2017). The police action was cynically codenamed "Operação Esperança Equilibrista", in a direct reference to Bosco's and Blanc's composition, prompting João Bosco to publicly repudiate the action and its abuse of the citation from the lyric: "This song was and remains, in the country's collective memory, a hymn to freedom and to the struggle to resume the democratic process. I do not authorise politically the use of this song by anyone betraying its fundamental spirit" (JoÃo..., 2017).

\section{Referências}

8 Melhores vídeos que viralizaram pedindo "Fora, Temer". Brasil de Fato, São Paulo, 19 July 2016. On-line. Available at: <https://goo.gl/AxZVKG>. Accessed on 22 Oct. 2017.

CAHE Rodrigues defende enredo da Imperatriz para o Carnaval 2017 sobre o povo Xingu. Carnavalesco, [S.l.], 7 Jan. 2017. On-line. Available at: <https://goo.gl/ ZAMvSR $>$. Accessed on 22 Oct. 2017.

Contra Temer, Geraldo Azevedo emociona público ao relembrar música de protesto. Revista Forum, Santos, 18 July 2016a. On-line. Available at: $<$ https://goo.gl/wbp3UF>. Accessed on 22 Oct. 2017.

Ем Ато em SP, Lula diz estar mais sereno do que magistrados que irão julgá-lo. Folha de S. Paulo, São Paulo, 19 Jan. 2018. Available at: <https://goo.gl/baVcvC>. Accessed on 8 Apr. 2018.

GALVÃo, Walnice Nogueira. MMBP: uma análise ideológica. In: Galvão, Walnice Nogueira. Saco de gatos: ensaios críticos. São Paulo: Duas Cidades, 1976. p. 93-96.

JoÃo Bosco reprova alusão ao "Hino da Anistia" em nome de operação da PF. Notícias UFMG, Belo Horizonte, 7 Dec. 2017. Available at: <https://goo.gl/NUpYa5>. Accessed on 8 Apr. 2018.

Lipsitz, George. Dangerous crossroads: popular music, postmodernism, and the poetics of place. London; New York: Verso, 1994. 
MARC, Isabelle. Travelling songs: on popular music transfer and translation. IASPM@fournal, [S.1.], v. 5, n. 2, p. 3-21, 2015.

Martín, María. Caetano Veloso abraça o movimento anti-Temer. El País, Rio de Janeiro, 23 May 2016. On-line. Available at: <https://goo.gl/jTzwP $4^{>}$. Accessed on 22 Oct. 2017.

Martins, Alexandra. "Ataque de conservadores autoritários". Estadão, São Paulo, 6 Dec. 2017. On-line. Available at: <https://goo.gl/RDCCPx>. Accessed on 8 Apr. 2018.

PrING-Mill, Robert. The roles of revolutionary song: a Nicaraguan assessment. Popular Music, Cambridge, v. 6, n. 2, p. 179-189, 1987.

RAP da greve: "PEC da decadência, reforma da Previdência, chega dessa indecência." Rede Brasil Atual, [S.1.], 27 Apr 2017. On-line. Available at: <https://goo.gl/ JC8Pg3>. Accessed on 22 Oct 2017.

RochA, Jan. Heading for impeachment. Latin America Bureau, 2 Apr. 2016. Online. Available at: <https://lab.org.uk/heading-for-impeachment/>. Accessed on 22 October 2017.

Santhiago, Ricardo. Flowers made of lead: paths, times, and emotions of protest music in Brazil. In: Friedman, Jonathan C. (Ed.). The Routledge history of social protest in popular music. New York: Routledge, 2013. p. 291-303.

TAtıt, Luiz. O cancionista: composição de canções no Brasil. São Paulo: Edusp, 1996.

Treece, David. Brazilian jive: from samba to bossa and rap. London: Reaktion, 2013.

Treece, David. Guns and roses: bossa nova and Brazil's music of popular protest, 1958-68. Popular Music, Cambridge, v. 16, n. 1, p. 1-29, 1997.

Treece, David. Não tem tradução? Tom e Vinicius em inglês. In: Matos, Cláudia Neiva de; Medeiros, Fernanda Teixeira; Oliveira, Leonardo Davino de (Eds.). Palavra cantada: estudos transdisciplinares. Rio de Janeiro: Eduerj, 2015. p. 11325.

Vasconcelos, Mônica. The São Paulo tapes. Produced by Robert Wyatt. [S.1.]: Mônica Vasconcelos, 2017.

Williams, Raymond. Marxism and literature. Oxford: Oxford University Press, 1977.

Recebido em 30 de outubro de 2017.

Aprovado em 24 de março de 2018. 


\section{Resumo/Abstract/Resumen}

\section{Trazendo as canções de resistência do Brasil a Londres: palavras e música em tradução}

\section{David Treece}

No contexto da crise brasileira pós-2016, o artigo investiga como um repertório de canções dos anos 1960 e 1970 pode ainda transmitir noções de resistência à repressão e ao autoritarismo através de meio século de história e através da distância cultural e linguística entre Brasil e Londres. Ele examina o potencial da tradução de canções para mediar esse processo, ao refletir brevemente num projeto prático, interativo e de base performativa realizado com públicos londrinos em 2017, intitulado "The São Paulo Tapes: Brazilian Resistance Songs Workshops". Depois de esboçar uma tipologia temática e estilística para os primeiros anos do regime militar, passa a argumentar que o período de recrudescimento repressivo pós-1968 marcou a mudança da canção de protesto para aquela de resistência, cuja linguagem poético-musical se tornou nitidamente lírica, e que esse traço teria necessariamente que se refletir no trabalho do tradutor.

Palavras-chave: Brasil, ditadura, linguagem, lírico, protesto, resistência, canção, tradução.

\section{Bringing Brazil's resistance songs to London: words and music in trans- lation}

\section{David Treece}

In the context of Brazil's post-2016 crisis, the article examines how a songwriting repertoire from the 1960 s and 70 os might still convey ideas of resistance to repression and authoritarianism across half a century of history and across the cultural and linguistic distance between Brazil and London. It explores the potential for song translation in mediating this process, reflecting briefly on a practical, performance-based interactive project undertaken with London audiences in 2017, entitled "The São Paulo Tapes: Brazilian Resistance Songs Workshops". After outlining a thematic and stylistic typology for the early years of military rule, it then argues that the post-1968 period of hardline repression marked a shift from the song of protest to that of resistance, whose poetic-musical language became distinctly lyrical, something that would need to be reflected in the translator's work.

Keywords: Brazil, dictatorship, language, lyrical, protest, resistance, song, translation. 
Llevando las canciones de resistencia de Brasil a Londres: palabras y música en traducción

\section{David Treece}

En el contexto de la crisis brasileña post 2016, el artículo investiga como un repertorio de canciones de los años 60 y 70 puede aún transmitir nociones de resistencia a la represión y al autoritarismo a través de medio siglo de historia y a través de la distancia cultural y lingüística entre Brasil y Londres. Se examina el potencial de la traducción de canciones para mediar en ese proceso, al reflexionar brevemente sobre un proyecto práctico, interactivo y de base performativa realizado con públicos londinenses en 2017, titulado "The São Paulo Tapes: Brazilian Resistance Songs Workshops". Tras esbozar una tipología temática y estilística para los primeros años del régimen militar, pasa a argumentar que el periodo de recrudecimiento represivo post 1968 marcó el cambio de la canción de protesta hacia la de resistencia, cuyo lenguaje poético-musical se hizo nítidamente lírico, y que esa marca tendría necesariamente que reflejarse en el trabajo del traductor.

Palabras clave: Brasil, dictadura, lenguaje, lírico, protesta, resistencia, canción, traducción. 